\title{
The number of urine specimens for bacteriological examination in women
}

\author{
Ertugrul Guclu, Tuba Damar, Oguz Karabay
}

1. Department of Infectious Diseases and Clinical Microbiology, Sakarya University Faculty of Medicine, Sakarya, Turkey.

Keywords: asymptomatic bacteriuria, women, urine culture. African Health Sciences 2014; 14(2):489

DOI: http://dx.doi.org/10.4314/ahs.v14i2.30

\section{Dear Editor}

We read the article entitled "Asymptomatic bacteriuria in diabetes mellitus patients in Southwest Cameroon", with great interest. As stated by the authors, asymtomatic bacteriuria (ASB) is a major concern in diabetics and especially in this group there is insufficient and discrepancy information on the occurence. ${ }^{1}$

The diagnosis of ASB is the most important step in managing ASB. As stated at the article the most important point for diagnosis is microbiological tests. In this context the number of specimens for culture is crucial. In guidelines ASB in men is defined as the isolation of $\geq 10^{5} \mathrm{cfu} / \mathrm{mL}$ bacteria in a single cleancatch voided urine specimen. On the other hand in women, two consecutive urine specimen is needed for an accurate diagnosis. ${ }^{2,3}$ However in the present study, authors did not define the number urine cultures in women. Whereas number of urine culture is crucial in women. We cannot say it is not contamination with only one positive culture.

\section{References}

1.Bissong ME, Fon PN, Tabe-Besong FO, Akenji TN. Asymptomatic bacteriuria in diabetes mellitus patients in Southwest Cameroon. Afr Health Sci. 2013 Sep;13(3):661-6

2. Nicolle LE, Bradley S, Colgan R, Rice JC, Schaeffer A, Hooton TM; Infectious Diseases Society of America; American Society of Nephrology; American Geriatric Society. Infectious Diseases Society of America guidelines for the diagnosis and treatment of asymptomatic bacteriuria in adults. Clin Infect Dis. 2005 Mar1;40(5):643-54.

3. Fekete T. Hooton TM. Approach to the adult with asymptomatic bacteriuria. http://www.uptodate.com/ contents/approach-to-the-adult-with-asymptomaticbacteriuria 